\title{
Haemodynamic effects of atrial natriuretic peptide in hypoxic chronic obstructive pulmonary disease
}

\author{
T K Rogers, W Sheedy, J Waterhouse, P Howard, A H Morice
}

\begin{abstract}
Background - Pulmonary artery pressure is elevated in patients with advanced chronic obstructive pulmonary disease (COPD). Release of atrial natriuretic peptide (ANP) is increased in pulmonary hypertension and this hormone may both selectively vasodilate pulmonary vessels and inhibit pulmonary vascular remodelling. The hypothesis that ANP has a physiological role in protection of the pulmonary circulation from pressure overload, and that it may be beneficial in patients with COPD, has been examined. Methods - Ten patients with hypoxic COPD were infused for 30 minute periods with saline followed by ANP at $0.4,2$, and $10 \mathrm{pmol} / \mathrm{kg} / \mathrm{min}$ respectively via a pulmonary artery catheter whilst monitoring haemodynamics and oxygenation.
\end{abstract}

Results - Levels of immunoreactive ANP (irANP) increased from a mean (SD) of $23(15) \mathrm{pmol} / 1$ to a maximum of 94 (41) pmol/1. Neither systemic blood pressure, cardiac output nor total systemic vascular resistance showed any correlation with irANP levels. There were negative correlations between levels of ANP and mean pulmonary artery pressure which fell from 28.7 to $25.9 \mathrm{~mm} \mathrm{Hg}$, pulmonary artery wedge pressure which fell from 6.5 to $4.6 \mathrm{~mm} \mathrm{Hg}$, and total pulmonary vascular resistance which fell from 489 to 428 dynes $\mathrm{sm}^{-5}$. There was a small fall in $\mathrm{PaCO}_{2}$ from 6.2 to $5.9 \mathrm{kPa}$, whilst venous admixture and oxygen delivery both increased non-significantly.

Conclusions - At these pathophysiological concentrations there was evidence that ANP selectively reduced right ventricular afterload. These data support the hypotheses that increased plasma levels of ANP may be beneficial in hypoxic COPD, and that endogenous ANP may ameliorate pulmonary hypertension in humans.

(Thorax 1994;49:233-239)

Reprint requests to: Clinic, Northern Genera Hospital, Herries Road, Sheffield S5 7AU, UK.

Received 5 May 1993 Returned to authors 22 July 1993

Revised version received 20 August 1993 Accepted for publication 22 November 1993
Pulmonary vascular resistance is elevated in patients with advanced chronic obstructive pulmonary disease (COPD $)^{1}$ associated with a progressive vascular remodelling of small pulmonary arteries and arterioles, ${ }^{2}$ although many other factors also contribute. As a result of increased afterload on the right ventricle, stroke volume and ejection fraction are depressed; cardiac output is maintained by a relative tachycardia. ${ }^{3}$ Oedema occurs during episodes of acute-on-chronic respiratory failure, a syndrome commonly known as "hypoxic cor pulmonale." This is an important step in the natural history of the disease: without treatment $65 \%$ of patients die within five years of the first episode. ${ }^{4}$

The role of vasodilators is controversial. ${ }^{56}$ There have been several short and medium term trials of vasodilator treatment in the condition, ${ }^{7-12}$ reviewed by Howard. ${ }^{5}$ Effects on arterial blood gases and cardiac output have been variable. Most agents have caused greater reduction of systemic than pulmonary vascular resistance. Some longer term trials have found that the pulmonary hypotensive effect disappeared with time, whilst others have found continued benefit at one year. No effect on prognosis has yet been shown.

There are three lines of evidence to suggest that atrial natriuretic peptide (ANP) may be helpful in patients with advanced COPD. Firstly, numerous studies in intact animals, ${ }^{13-15}$ in animal isolated lung preparations, ${ }^{1617}$ and in isolated animal ${ }^{18-20}$ and human vessels ${ }^{2122}$ have suggested that the vasodilator activity of ANP may be selective for the pulmonary vascular bed. Secondly, there is evidence that ANP can inhibit vascular remodelling, both in vitro ${ }^{23}$ and in the rat model of hypoxic pulmonary hypertension. ${ }^{24-26}$ This has been achieved both by chronic infusion of $\mathrm{ANP}^{24}$ and by the inhibition of ANP metabolism with neutral endopeptidase inhibitors. ${ }^{2526}$ Thirdly, the well known diuretic and natriuretic effects of $\mathrm{ANP}^{27}$ may have a value in reversing the episodic fluid retention. Against these possible benefits is the potential disadvantage that, by acutely antagonising hypoxic pulmonary vasoconstriction, ANP may impair ventilationperfusion matching and exacerbate hypoxia.

In this study we have examined the response of patients with hypoxic COPD to levels of ANP seen in severe pulmonary hypertension. Physiological release was simulated by infusing ANP into the main pulmonary artery in 10 subjects. The hypotheses to be tested were (1) that these levels of ANP, achievable by pharmacological modification of ANP metabolism, ${ }^{28}$ have a beneficial effect on pulmonary haemodynamics in COPD; and (2) that ANP has a specific effect on the pulmonary vasculature. Finding the hypotheses to be correct would suggest that inhibitors of ANP metabolism may be of therapeutic use in COPD, and 
that the high concentrations of ANP found in severe pulmonary hypertension may have a homeostatic function.

\section{Methods}

PATIENTS

Local ethical committee approval for the study was obtained. A power calculation showed that, to allow an $80 \%$ chance of detecting a fall in pulmonary artery pressure (PPA) of $5 \mathrm{~mm} \mathrm{Hg}$ by a two tailed paired $t$ test with $\alpha=0.05$, assuming a variance of the difference between pairs of 28 (from Adnot et $a l^{29}$ ), at least nine patients would be required. Ten patients were therefore enrolled, selected from a respiratory outpatient clinic and included after giving formal written consent.

\section{Inclusion criteria}

Patients were included in the study if they satisfied all the following conditions: severe chronic airflow obstruction with $\mathrm{FEV}_{1} / \mathrm{FVC}$ less than $60 \%$; history of more than 10 pack years of tobacco consumption; stable respiratory failure with $\mathrm{PaO}_{2}<8.0 \mathrm{kPa}$.

\section{Exclusion criteria}

Patients were excluded if they had any clinical evidence of ischaemic or valvular heart disease, any significant intercurrent disease, or had had an acute exacerbation of COPD during the three months before the study. Because ANP is known to cause an increase in haematocrit as a result of a shift of fluid from the intravascular space, any patient with a haematocrit of $>50 \%$ was also to have been excluded, although no otherwise eligible subject was excluded on the basis of this criterion.

\section{STUDY PROTOCOL}

Patients were seen by a dietician to establish a constant salt intake over the week before the study day, and were admitted to hospital either on the evening before or the morning of the study. On rising patients were asked to micturate. They were not given oxygen supplementation or diuretic treatment on the day of the study, but were allowed other morning medication and a light breakfast. They then remained nil by mouth until completion of the study. Just before commencement of the study patients were again asked to void the bladder, storing an aliquot of urine at $-20^{\circ} \mathrm{C}$.

Right heart catheterisation was performed in an operating theatre under sterile conditions. A 7 French gauge, five lumen, flow directed, balloon tipped, thermodilution catheter (Criticath, Spectramed Inc) was introduced through a brachial or internal jugular vein. Placement of the catheter tip in the pulmonary artery was determined by monitoring the pressure trace during advancement, if necessary with the aid of an image intensifier.
The catheter was clamped in the position at which a pulmonary artery wedge pressure could be recorded. After catheter insertion patients sat semirecumbent for the duration of the study.

A 21-gauge intravenous cannula (Viggo) was positioned in a forearm vein for peripheral venous blood samples. Transcutaneous oxygen saturation $\left(\mathrm{SaO}_{2}\right)$ and pulse rate were continuously monitored with a pulse oximeter (Minolta Pulsox-7). Systemic blood pressure was measured with a Dynamap sphygmomanometer on the contralateral arm. Cardiac output measurements were made in triplicate, each thermal bolus consisting of $10 \mathrm{ml}$ of room temperature saline. Cardiac output was determined with a Gould Model SP2009B recorder and bedside computer. Arterial blood gas samples were taken from the radial artery during the baseline saline infusion and maximal ANP infusion.

ANP INFUSION

There were four infusion periods, each lasting 30 minutes. For the first period saline was infused at the same rate as that required for the maximum dose of ANP. Incremental doses of ANP were then infused, equivalent to $0.4,2$, and $10 \mathrm{pmol} / \mathrm{kg} / \mathrm{min}$ (called ANP-1, ANP-2, and ANP-3, respectively). We have previously shown that these doses produce plasma levels within the pathophysiological range and have renal effects when infused into normal volunteers. ${ }^{30}$

The following measurements were taken after 15 minutes of each infusion period: pulmonary artery pressure, cardiac output, pulse rate, systemic blood pressure, arterial oxygen saturation $\left(\mathrm{SaO}_{2}\right)$, and mixed venous blood gas tensions. Venous blood samples were taken from the peripheral venous cannula for immediate centrifugation and were stored at $-20^{\circ} \mathrm{C}$ for subsequent assay of plasma ANP concentration. Fifteen minutes after the end of the final infusion of ANP a further set of recordings was made and urine collected and stored at $-20^{\circ} \mathrm{C}$.

\section{MATERIALS}

Human synthetic ANP (Sigma Chemical Company, Poole, Dorset) was dissolved in $0.05 \mathrm{~mol} / 1$ acetic acid (FSA Laboratory Supplies, Loughborough) and sterilised by passage through a Millex GV, low protein binding filter (Millipore, Harrow, Middlesex), the first $1.0 \mathrm{ml}$ being discarded. It was then diluted to $2 \mathrm{nmol} / \mathrm{ml}$ in a solution of $50 \%$ normal saline (Baxter, Thetford) and $50 \%$ Haemaccel (Hoechst, Hounslow, Middlesex) to minimise adsorption of ANP to surfaces. Vials containing $15 \mathrm{ml}$ of the solution were frozen at $-20^{\circ} \mathrm{C}$ until used.

Before infusion ANP was thawed and diluted to $0.5 \mu \mathrm{mol} / 1$ with normal saline. The solution was infused in a syringe driver (Vickers) via the "CVP medication" lumen of the pulmonary artery catheter. 
ANP RADIOIMMUNOASSAY

Blood samples were centrifuged immediately at $4^{\circ} \mathrm{C}$ and $3000 \mathrm{rpm}$ for 20 minutes. Plasma was aspirated and stored in polypropylene vials at $-20^{\circ} \mathrm{C}$. Extraction of plasma ANP was carried out using Sep-Pak $\mathrm{C} 18$ cartridges (Waters Associates). One millilitre of plasma was acidified with trifluoroacetic acid $(0 \cdot 1 \%)$ and applied to a primed cartridge which was then washed with $5 \mathrm{ml} 0.1 \%$ trifluoroacetic acid and eluted with $2.0 \mathrm{ml}$ of $70 \%$ acetonitrile. Samples were vacuum dried and stored at $-20^{\circ} \mathrm{C}$ for up to one week until assayed. Alpha human ANP radioimmunoassay kits (RIK8798, Peninsula Laboratories Inc) were used. Plasma samples were reconstituted with $1 \mathrm{ml}$ of the buffer and assayed in duplicate.

Between $20 \%$ and $40 \%$ of the label was bound in the absence of unlabelled peptide and $1-2 \%$ in the absence of antibody. The intraassay coefficient of variation was $13 \%$ and the interassay coefficient of variation was $6 \%$. The $\mathrm{IC}_{50}$ for the assays was $50-90 \mathrm{pg} / \mathrm{ml}$. Recovery of iodine-125 was $70-90 \%$ using this extraction method. No correction was made for extraction losses.

CALCULATIONS AND STATISTICAL METHODS Total pulmonary vascular resistance (TPVR) was calculated by:

TPVR $\left(\right.$ dynes s cm $\left.{ }^{-5}\right)=\frac{\text { PPA }(\mathrm{mm} \mathrm{Hg})}{Q(1 / \mathrm{min})} \times 80$

Arteriolar PVR (PVRART) was calculated by:

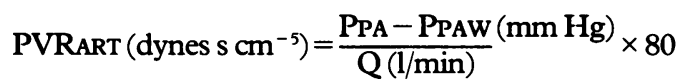

where PPA is pulmonary artery pressure, PPAw is pulmonary artery wedge pressure, and $Q$ is cardiac output.

Mean systemic arterial pressure (mean PsA) was calculated by:

mean PSA $=$ SBPDIAST $+\frac{(\text { SBPsysT }- \text { SBPDIAST })}{3}$

where SBPSYST is systemic blood pressure, and SBPDIAST is systemic diastolic blood pressure.

Shunt fraction was calculated from the shunt equation. ${ }^{31}$ Coefficient of oxygen delivery (COD) was calculated from:

$$
\mathrm{COD}=\frac{\mathrm{CaO}_{2}}{\mathrm{CaO}_{2}-\mathrm{CvO}_{2}}
$$

where $\mathrm{CaO}_{2}$ is the oxygen content of arterial blood and $\mathrm{CvO}_{2}$ is the oxygen content of mixed venous blood.

The significance of increases in levels of immunoreactive ANP (irANP) during the different infusion periods was assessed by a single factor analysis of variance, followed by multiple range testing (using the Microsoft Excel statistical function). The relations between ANP levels and haemodynamic parameters measured at each time point were assessed by regression analysis in groups. ${ }^{32}$ The individual regressions of the dependent variable in question - for example, PPA on log concentration of irANP level during saline and ANP infusion (the independent variable) - for each patient were calculated. The significance of the common slope was assessed by analysis of variance for differences between the regression slopes. Calculations were performed on a Microsoft Excel spreadsheet. Parameters measured at two time points only were compared by a two tailed, Student's paired $t$ test (using the Microsoft Excel statistical function). A p value of $<0.05$ was considered to be statistically significant.

\section{Results}

\section{PATIENT CHARACTERISTICS}

The mean age of the patients was 67.9 (range 61-79) years and seven of the 10 were men (table 1). All had severe fixed airflow obstruction with $\mathrm{FEV}_{1} / \mathrm{FVC}$ ranging from $21 \%$ to $53 \%$, and a history of heavy tobacco consumption of between 10 and 50 pack years. One patient (no. 5) probably had additional fibrotic lung disease with more severe hypoxia than would be expected for his degree of airflow obstruction. All had arterial hypoxaemia, and six patients were hypercapnic. All patients were taking regular inhaled $\beta_{2}$ agonists and some were also taking inhaled anticholinergics; none was taking a theophylline.

Six patients were receiving long term domiciliary oxygen therapy, two (nos 6 and 10) were about to commence it, and two did not have

Table 1 Patient characteristics, arterial blood gas tensions, and lung function data

\begin{tabular}{|c|c|c|c|c|c|c|c|c|c|c|c|c|c|}
\hline \multirow{2}{*}{$\begin{array}{l}\text { Patient } \\
\text { no. }\end{array}$} & \multirow[t]{2}{*}{ Age } & \multirow[t]{2}{*}{ Sex } & \multirow{2}{*}{$\begin{array}{l}\text { Pack } \\
\text { years }\end{array}$} & \multicolumn{2}{|l|}{ LTOT } & \multirow{2}{*}{$\begin{array}{l}F E V_{l} \\
(l)\end{array}$} & \multirow{2}{*}{$\begin{array}{l}F E V_{1} \\
(\% \text { pred })\end{array}$} & \multirow{2}{*}{$\begin{array}{l}F V C \\
(l)\end{array}$} & \multirow{2}{*}{$\begin{array}{l}\mathrm{PaO}_{2} \\
(\mathrm{kPa})\end{array}$} & \multirow{2}{*}{$\begin{array}{l}\mathrm{PaCO}_{2} \\
(\mathrm{kPa})\end{array}$} & \multirow{2}{*}{$\begin{array}{l}H^{+} \\
(\text {nmol/l) })\end{array}$} & \multirow{2}{*}{$\begin{array}{l}\text { Past history } \\
\text { of oedema }\end{array}$} & \multirow{2}{*}{$\begin{array}{l}\text { Baseline PPA } \\
(\mathrm{mm} \mathrm{Hg})\end{array}$} \\
\hline & & & & Prescribed & Duration (days) & & & & & & & & \\
\hline $\begin{array}{r}1 \\
2 \\
3 \\
4 \\
5 \\
6 \\
7 \\
8 \\
9 \\
10\end{array}$ & $\begin{array}{l}67 \\
79 \\
69 \\
69 \\
63 \\
64 \\
70 \\
61 \\
65 \\
72\end{array}$ & $\begin{array}{l}M \\
M \\
M \\
M \\
M \\
F \\
F \\
F \\
M \\
M\end{array}$ & $\begin{array}{l}22 \\
10 \\
35 \\
21 \\
35 \\
45 \\
30 \\
20 \\
50 \\
35\end{array}$ & $\begin{array}{l}\text { Yes } \\
\text { Yes } \\
\text { No } \\
\text { Yes } \\
\text { Yes } \\
\text { No } \\
\text { Yes } \\
\text { Yes } \\
\text { No } \\
\text { No }\end{array}$ & $\begin{array}{r}282 \\
636 \\
\\
1685 \\
1326 \\
\\
539 \\
377\end{array}$ & $\begin{array}{l}0.90 \\
0.73 \\
0.93 \\
1.03 \\
1.86 \\
0.82 \\
0.80 \\
0.30 \\
0.80 \\
0.49\end{array}$ & $\begin{array}{l}40 \\
32 \\
33 \\
47 \\
79 \\
37 \\
42 \\
15 \\
26 \\
19\end{array}$ & $\begin{array}{l}2 \cdot 20 \\
2 \cdot 10 \\
2 \cdot 09 \\
2 \cdot 06 \\
3 \cdot 51 \\
1 \cdot 66 \\
2 \cdot 10 \\
0 \cdot 70 \\
2 \cdot 00 \\
2 \cdot 38\end{array}$ & $\begin{array}{l}6.90 \\
6.87 \\
7.78 \\
6.59 \\
5.81 \\
7.24 \\
5.93 \\
5 \cdot 78 \\
7.88 \\
6.66\end{array}$ & $\begin{array}{l}\cdot 60 \\
5.04 \\
6 \cdot 70 \\
7.00 \\
4.72 \\
6.83 \\
7 \cdot 16 \\
7.00 \\
6.65 \\
5.39\end{array}$ & $\begin{array}{l}38 \\
34 \\
39 \\
39 \\
34 \\
43 \\
38 \\
37 \\
35 \\
36\end{array}$ & $\begin{array}{l}\text { Yes } \\
\text { Yes } \\
\text { No } \\
\text { No } \\
\text { No } \\
\text { Yes } \\
\text { No } \\
\text { No } \\
\text { Yes } \\
\text { Yes }\end{array}$ & $\begin{array}{l}33 \cdot 5 \\
35 \cdot 4 \\
24 \cdot 1 \\
43 \cdot 6 \\
20 \cdot 5 \\
34 \cdot 8 \\
20 \cdot 8 \\
29 \cdot 9 \\
31 \cdot 2 \\
25 \cdot 9\end{array}$ \\
\hline Mean & 68 & & 30 & $6 / 10$ & 808 & 0.87 & 37 & 2.08 & 6.74 & $6 \cdot 21$ & 37 & $5 / 10$ & $30 \cdot 0$ \\
\hline
\end{tabular}

LTOT = long term oxygen therapy; FEV $_{1}=$ forced expiratory volume in one second; $\%$ pred = percentage of predicted; FVC= forced vital capacity; PPA = pulmonary artery pressure. 
sufficiently severe hypoxaemia to qualify (nos 3 and 9) having a $\mathrm{PaO}_{2}$ greater than $7 \cdot 3 \mathrm{kPa}$. Five patients had a history of oedema, although none was in overt cor pulmonale during the study.

\section{PLASMA ANP LEVELS}

As can be seen in fig 1 there was a dose dependent increase in serum levels of irANP (ANOVA $\mathrm{p}<1 \times 10^{-13}$ ). Both of the higher rates of ANP infusion (ANP-2 and ANP-3) resulted in significant increases, by $89 \%$ $(\mathrm{p}<0.005)$ and $422 \%(\mathrm{p}<0.0005)$ of baseline values, respectively.

One patient (no. 4) showed an atypical response. The resting ANP level was the highest for the group at $50 \mathrm{pmol} / \mathrm{l}$, and levels were not increased by subsequent ANP infusion. This subject also had the highest resting mean PPA at $37 \mathrm{~mm} \mathrm{Hg}$ and was the only subject whose PPA did not fall during ANP infusion; indeed it rose to $40 \mathrm{~mm} \mathrm{Hg}$. He experienced a fall in $\mathrm{PaO}_{2}$ during ANP-3 from $6 \cdot 6$ to $6 \cdot 1 \mathrm{kPa}$, and $\mathrm{PaCO}_{2}$ fell from $7 \cdot 0$ to $6.6 \mathrm{kPa}$.

\section{HAEMODYNAMIC EFFECTS}

Pulmonary haemodynamics

Haemodynamic effects of ANP infusion are shown in table 2 . The baseline mean pulmonary artery pressure and total pulmonary vascular resistance were elevated in all patients (ranges $20-38 \mathrm{~mm} \mathrm{Hg}$ and $292-$ 740 dynes $\mathrm{s} \mathrm{cm}^{-5}$, respectively). Mean pulmonary artery pressure showed a significant, negative correlation with irANP levels, falling from a mean (SD) of $28.7(6.4) \mathrm{mm} \mathrm{Hg}$ during saline infusion to $25.9(6.9) \mathrm{mm} \mathrm{Hg}$ at maximum infusion rate $(r=-0.55, \mathrm{p}<0.005$; figs 2 and 3). Total pulmonary vascular resistance was also significantly correlated, with a fall of $12 \%$ from 489 (168) to 428 (151) dynes $\mathrm{sm}^{-5}$ $(r=-0.46, \mathrm{p}<0.005 ;$ fig 4$)$. There was no correlation with pulmonary arteriolar resistance which fell from 329 (125) to 299 (96) dynes $\mathrm{sm}^{-5}(r=-0 \cdot 11, \mathrm{p}=0 \cdot 4$; table 2$)$.

Systemic haemodynamics

Neither cardiac index, total systemic vascular

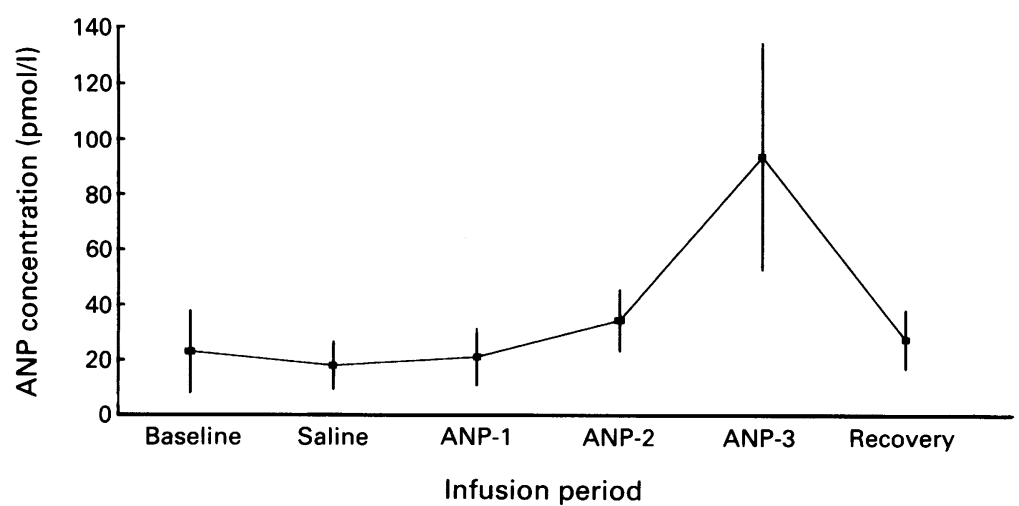

Figure 1 Mean (SD) immunoreactive plasma levels of ANP during different infusion periods: saline = saline at maximum infusion rate used $A N P-1=0.4 \mathrm{pmol} / \mathrm{kg} / \mathrm{min} A N P ; A N P-2=2 \mathrm{pmol} / \mathrm{kg} / \mathrm{min} A N P$ $A N P-3=10 \mathrm{pmol} / \mathrm{kg} / \mathrm{min}$ ANP; recovery $=$ no infusion. resistance, nor systemic blood pressure correlated with irANP levels (table 2). Total systemic vascular resistance fell by $5 \%$ from 1887 dynes $\mathrm{s} \mathrm{cm}^{-5}$ during saline infusion to 1799 dynes $\mathrm{s} \mathrm{cm}^{-5}$ at ANP-3 $(r=-0.07$, $\mathrm{p}=0.98$ ). In four patients the Ppaw was unobtainable, but none of the remaining patients had an elevated resting value (range 5.2$9 \mathrm{~mm} \mathrm{Hg}$ ). There was a significant correlation between ANP levels and pulmonary artery wedge pressure, which fell from $6.5(1 \cdot 1)$ to 4.6 $(1.4) \mathrm{mm} \mathrm{Hg}$ at the maximum dose $(r=-0.80$, $\mathrm{p}<0.001$; fig 5). Furthermore, PPAW was strongly correlated with both PPA $(r=0.67$, $\mathrm{p}<0.01)$ and TPVR $(r=0.60, \mathrm{p}<0.01)$ in the six subjects in whom it was measured.

\section{GAS EXCHANGE}

There was a small but significant fall in $\mathrm{PaCO}_{2}$ from 6.2(0.9) to $5.9(0.9) \mathrm{kPa}, \mathrm{p}<0.0005$ (table 2). The mean $\mathrm{PaO}_{2}$ showed no significant change from $6.7(0.8) \mathrm{kPa}$ at baseline to 6.9 $(0 \cdot 9) \mathrm{kPa}$ at ANP-3. Individual patients varied in their response: in five patients $\mathrm{PaO}_{2}$ increased by a mean of 0.6 (range +0.3 to $+0 \cdot 8) \mathrm{kPa}$, and in five patients it fell by a mean of -0.4 (range -0.2 to -0.6 ) $\mathrm{kPa}$. The oxygen saturation measured by pulse oximetry suggested a significant, positive correlation between ANP levels and $\mathrm{SaO}_{2} \quad(r=0.42$, $\mathrm{p}<0.01$ ).

To determine the right to left shunt fraction, mixed venous blood gases were assessed in nine patients. As might be expected shunt fraction, which is partly derived from $\mathrm{PaO}_{2}$, also showed a variable response to ANP infusion between patients, increasing in five and falling in four.

\section{RENAL EFFECTS}

Urinary volume was not assessed. However, creatinine concentration fell from $9.3(3.9)$ to $5.9(3.6) \mathrm{mmol} / \mathrm{l}(\mathrm{p}<0.02)$, and the ratio of urinary sodium to creatinine rose from 12 (11) to $22(12)(\mathrm{p}<0.002)$.

\section{ADVERSE EFFECTS}

The ANP infusion was well tolerated. No patient required supplemental oxygen during the procedure. One patient felt transiently faint upon removal of the right heart catheter, associated with systemic hypotension. This resolved within three minutes and was typical of a vasovagal episode.

\section{Discussion}

As expected, all patients had evidence of a restricted pulmonary vascular bed with raised mean pulmonary artery pressures, total pulmonary vascular resistance and, in the six in whom it could be measured, elevated pulmonary arteriolar resistance. The normal PPAw measurements and normal cardiac index suggest that the left ventricular function of the group was unimpaired.

As we have previously found, ${ }^{33}$ mean (SD) 
Table 2 Mean (SD) ANP levels, haemodynamic effects, and blood gas changes during ANP infusion

\begin{tabular}{|c|c|c|c|c|c|c|c|c|}
\hline & \multirow{2}{*}{$\begin{array}{l}\text { Number of } \\
\text { observations }\end{array}$} & \multicolumn{5}{|l|}{ Infusion period } & \multirow[t]{2}{*}{$\mathbf{r}$} & \multirow[t]{2}{*}{$p$} \\
\hline & & Saline & $A N P-1$ & $A N P-2$ & $A N P-3$ & Recovery & & \\
\hline $\operatorname{irANP}(\mathrm{pmol} / \mathrm{l})$ & 10 & $18(8)$ & $21(10)$ & $35(11)$ & $94(41)$ & $28(11)$ & & $<1 \times 10^{-13}$ \\
\hline Cardiac index $\left(1 / \mathrm{min} / \mathrm{m}^{2}\right)$ & 10 & $2.80(0.20)$ & $2.83(0.21)$ & $2.74(0.19)$ & $2.85(0 \cdot 17)$ & $2.71(0.22)$ & -0.05 & NS \\
\hline SBPsYST (mm Hg) & 10 & $149(12)$ & $149(13)$ & $150(16)$ & $146(16)$ & $140(18)$ & $-0 \cdot 14$ & NS \\
\hline SBPDIAST (mm Hg) & 10 & 90 (11) & $89(9)$ & $92(14)$ & $88(17)$ & $90(18)$ & -0.09 & NS \\
\hline Mean SBP (mm Hg) & 10 & $112(15)$ & $110(10)$ & $110(10)$ & $110(10)$ & $106(16)$ & $-0 \cdot 16$ & NS \\
\hline TSVR (dynes $\mathrm{cm}^{-5}$ ) & 10 & $1887(496)$ & $1800(332)$ & $1887(495)$ & $1799(444)$ & $1831(467)$ & -0.07 & NS \\
\hline PpAw $(\mathrm{mm} \mathrm{Hg})$ & 6 & $6 \cdot 5(1 \cdot 1)$ & $5 \cdot 7(1 \cdot 3)$ & $4.9(2.0)$ & $4 \cdot 6(1 \cdot 4)$ & $5 \cdot 3(1 \cdot 3)$ & -0.80 & $<0.001$ \\
\hline PPA,SYST $(\mathrm{mm} \mathrm{Hg})$ & 10 & $45 \cdot 9(14 \cdot 1)$ & $45.4(14 \cdot 1)$ & $40 \cdot 6(7 \cdot 8)$ & $37.7(6.5)$ & $42 \cdot 8(14 \cdot 2)$ & -0.55 & $<0.005$ \\
\hline PPA,DIAST (mm Hg) & 10 & $19 \cdot 6(5 \cdot 5)$ & $20 \cdot 3(5 \cdot 4)$ & $19 \cdot 1(5 \cdot 7)$ & $20 \cdot 1(6.5)$ & $22.8(6.8)$ & -0.07 & NS \\
\hline Mean PPA (mm Hg) & 10 & $28.7(6.4)$ & $28 \cdot 2(7 \cdot 2)$ & $27 \cdot 0(6 \cdot 7)$ & $25.9(6.9)$ & $28.8(9.8)$ & -0.55 & $<0.005$ \\
\hline TPVR (dynes s cm ${ }^{-5}$ ) & 10 & $489(168)$ & $464(151)$ & $468(167)$ & $428(151)$ & 501 (195) & -0.46 & $<0.005$ \\
\hline PAR (dynes $\mathrm{s} \mathrm{cm}^{-5}$ ) & 6 & $329(125)$ & 337 (126) & $328(79)$ & $299(96)$ & $365(182)$ & -0.11 & NS \\
\hline Pulse rate (beats $/ \mathrm{min}$ ) & 10 & $82(10)$ & $82(9)$ & $86(12)$ & 89 (12) & $87(10)$ & 0.76 & $<0.001$ \\
\hline $\mathrm{SaO}_{2}(\%)$ & 10 & $85.9(1.0)$ & $86.5(0.9)$ & $87 \cdot 6(1 \cdot 0)$ & $87.6(1.0)$ & $87 \cdot 7(0 \cdot 8)$ & 0.42 & $<0.01$ \\
\hline $\mathrm{PaO}_{2}(\mathrm{kPa})$ & 10 & $6.7(0.8)$ & & & $6.9(0.9)$ & & & NS \\
\hline $\mathrm{PaCO}_{2}(\mathrm{kPa})$ & 10 & $6.2(0.9)$ & & & $5.9(0.9)$ & & & $<0.0005$ \\
\hline Shunt fraction (\%) & 9 & $16.4(7.2)$ & & & $18.6(10.5)$ & & & \\
\hline Coefficient of $\mathrm{O}_{2}$ delivery & 9 & $3.0(0.2)$ & & & $3 \cdot 2(0 \cdot 2)$ & & & NS \\
\hline
\end{tabular}

irANP=immunoreactive ANP; SBPsYST=systemic systolic blood pressure; SBPDIAST= systemic diastolic blood pressure; TSVR=total systemic vascular resistance; PPAW = pulmonary artery wedge pressure; $\mathrm{PPA}=$ mean pulmonary artery pressure; $\mathrm{TPVR}=$ total pulmonary vascular resistance; $\mathrm{PAR}=$ pulmonary arteriolar resistance. Infusions ANP-1, ANP-2, and ANP-3 were $0 \cdot 4,2$, and $10 \mathrm{pmol} / \mathrm{kg} / \mathrm{min}$ respectively.

Note: $\mathrm{p}$ and $r$ values refer to linear regression analysis in groups for variables assessed during each infusion period, and to paired, two tailed Student's $t$ tests for the variables assessed at two time points only.

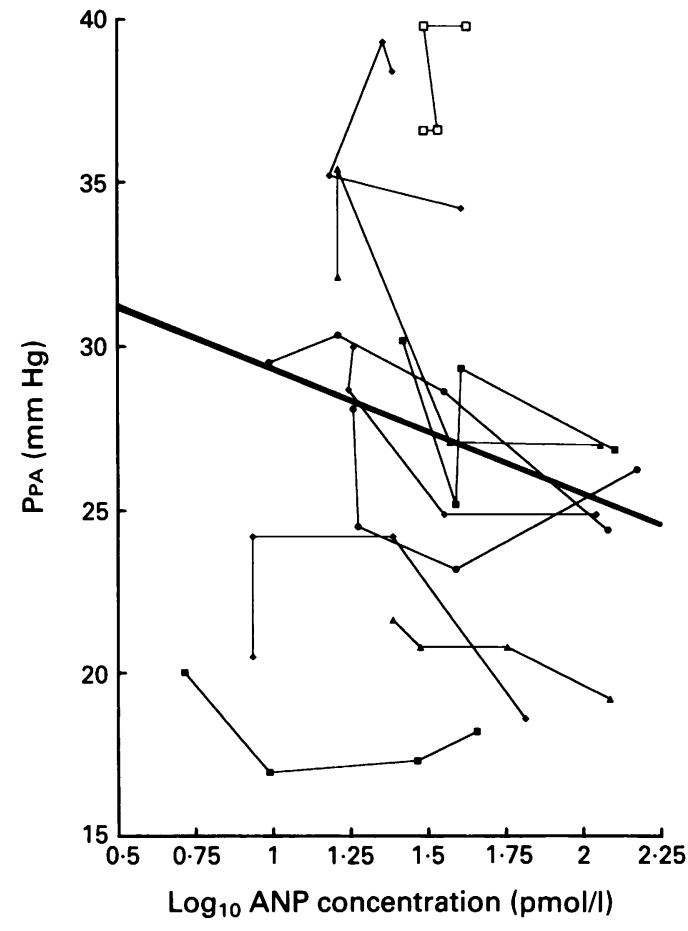

Figure 2 Individual dose-response relations between mean pulmonary artery pressure and $\log _{10}$ levels of immunoreactive ANP. ANP levels did not change appreciably in patient no. 4 (open squares). The common regression line is shown in bold.

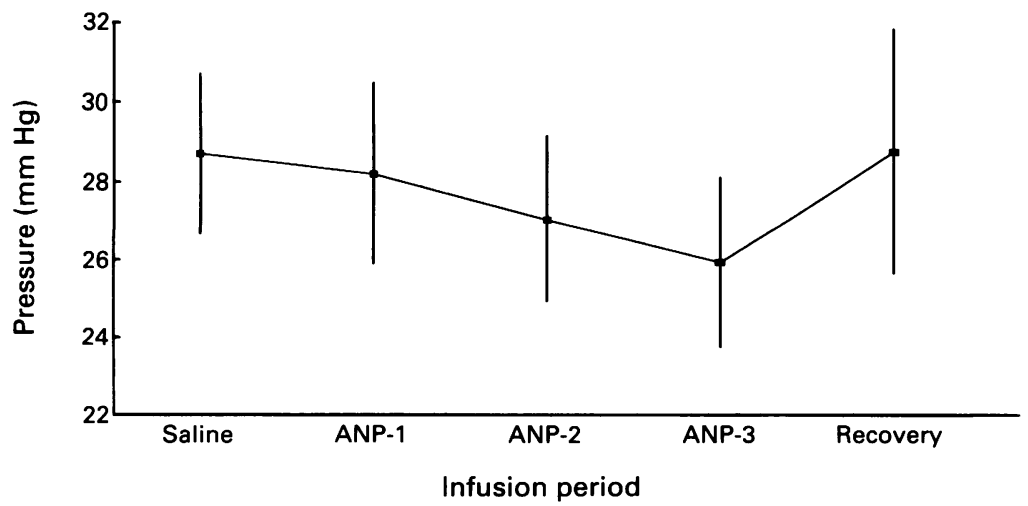

Figure 3 Mean ( $S E$ ) pulmonary artery pressure during different infusion periods. See legend to fig 1 for abbreviations. baseline serum irANP levels were mildly elevated at 23 (15) pmol/l compared with the levels of less than $12 \mathrm{pmol} / \mathrm{l}$ found by our assay in normal subjects. Infusion of ANP was associated with a dose related increase in plasma irANP levels up to concentrations previously found in patients with severe pulmonary hypertension. ${ }^{34}$ The primary endpoint of this study was to establish the effect of such pathophysiological levels of ANP on the pulmonary circulation in COPD. The observed fall in mean pulmonary artery pressure was modest, but correlated significantly with ANP levels. Our patients also showed a renal response to ANP as shown by the significant increase in urinary sodium to creatinine ratio, similar to that we have previously described in normal volunteers. ${ }^{30}$

The reduction in TPVR was a result of the pulmonary artery pressure falling in the presence of a stable cardiac output. The reduction of right ventricular afterload appears to have been due in large part to the fall in Ppaw, accounting for approximately $36 \%$ of the reduction in TPVR in the subjects in whom it was measurable. Indeed, a fall in PpAw has been a consistent finding when ANP has been infused variously into animals, normal human volunteers, ${ }^{35}$ and patients with heart failure. ${ }^{36-38}$ Pulmonary arteriolar resistance, representing the degree of vasoconstriction present in the pulmonary vascular bed, did not change significantly in the patients in whom it could be calculated. The data do not allow conclusions to be drawn on whether pulmonary vasodilatation occurred at these levels of irANP, and whether this mechanism contributed to the fall in right ventricular afterload.

Caution should be exercised in interpreting the significance of changes in the multiple secondary and derived endpoints examined in this study. However, there was little evidence for effects of the infusion on systemic haemodynamics, with the exception of PPAw and heart rate. ANP infusion was not associated with changes in systemic arterial pressure with or in total systemic vascular resistance (TSVR). TSVR is the result of both the pres- 


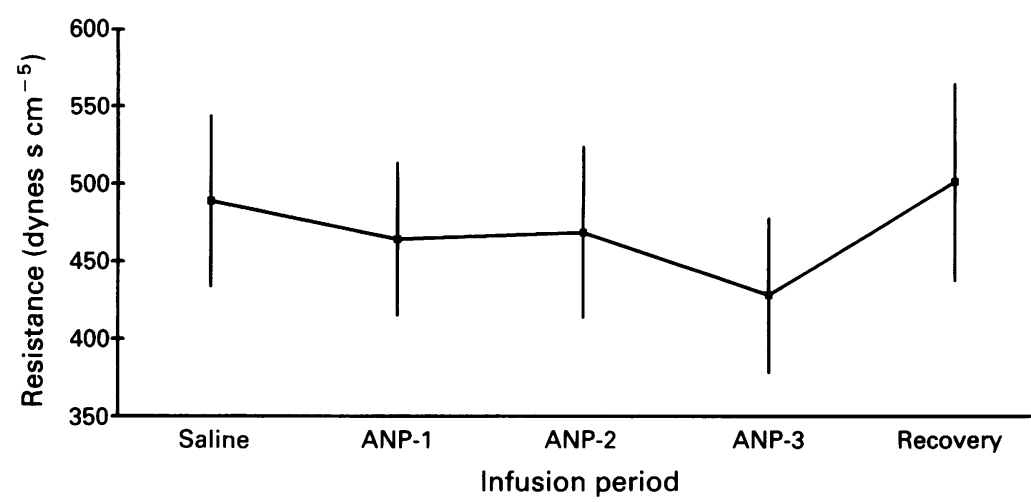

Figure 4 Mean (SE) total pulmonary vascular resistance during different infusion periods. See legend to fig 1 for abbreviations.

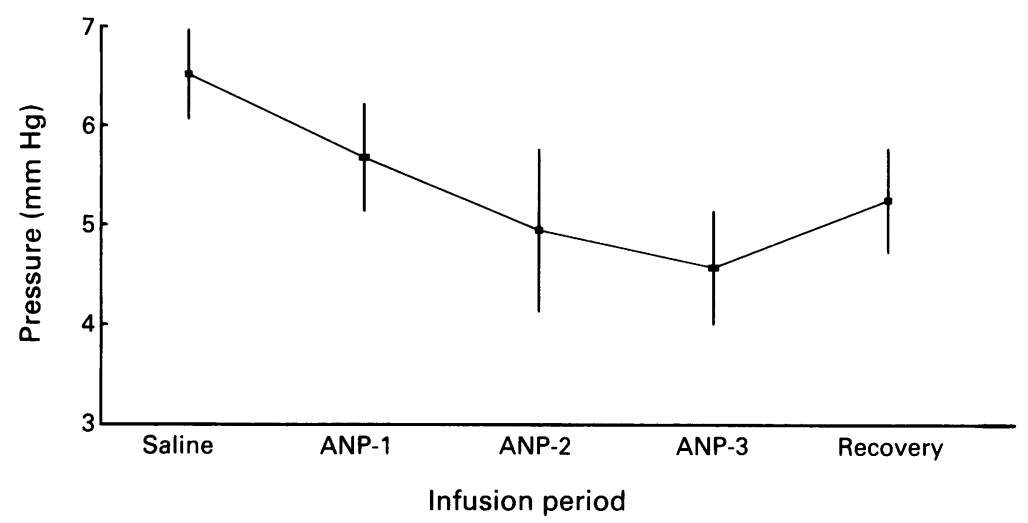

Figure 5 Mean ( $S E$ ) pulmonary artery wedge pressure during different infusion periods. See legend to fig 1 for abbreviations.

sure drop across the systemic circulation and right atrial pressure. Because right atrial pressure is lowered by ANP infusion, ${ }^{39}$ the lack of change in TSVR further suggests that relaxation did not occur in systemic resistance vessels.

Pulse rate showed a small but significant increase, probably accounting for cardiac output being maintained in the face of the observed fall in preload. The lack of an increase in cardiac output has also been found in experimental animals and normal human volunteers, ${ }^{35}$ and distinguishes ANP from other vasodilators. The likely explanation is that ANP causes a reduction in cardiac preload and is a poor systemic vasodilator.

The fall in pulmonary vascular resistance was achieved without mean arterial oxygen tension falling, or a significant increase in venous admixture. No patient developed severe hypoxaemia or other adverse haemodynamic effects from ANP infusion. In agreement with a previous study, ${ }^{29} \mathrm{PaCO}_{2}$ fell in all patients during ANP infusion, although this may have been attributable to anxiety or some other factor (see below). The unexpected finding of an improvement in shunt fraction in some of our patients may reflect the derived nature of this parameter. Alternative explanations include mild vasodilatation causing pulmonary blood flow to be diverted from units with very low ventilation-perfusion ratios to those with higher values, or to bronchodilatation improving the distribution of ventila- tion. Interestingly, it has recently been reported that ANP infusion increased $\mathrm{PaO}_{2}$ and reduced the alveolar-arterial oxygen difference in normal volunteers exposed to hypobaric hypoxia. $^{40}$

Patient no. 4 showed no increase in plasma levels of irANP during the infusion, had a high resting ANP level, and was alone in not showing a fall in pulmonary artery pressure. Although the lack of increase in irANP is unexplained, this does provide support for the changes in pulmonary haemodynamics observed in the remaining patients being a result of an increase in plasma ANP levels. Conversely, the fall in $\mathrm{PaCO}_{2}$ in this patient suggests that this change, which was seen in all patients, may not have been attributable to ANP.

One other study has examined the effect of ANP infusion in human pulmonary hypertension. Adnot $e t$ a ${ }^{29}$ infused incremental doses of ANP over 10 minute periods via a peripheral vein in a group of seven patients with hypoxic COPD. They achieved much higher peripheral blood irANP levels than in our study, with even the lowest dose increasing the concentration from a baseline value of $44 \mathrm{pmol} / 1$ up to $120 \mathrm{pmol} / \mathrm{l}$. These higher plasma concentrations had a significant depressor effect on the systemic circulation. These authors also found evidence of pulmonary selectivity, however, with a much greater fall in pulmonary than systemic vascular resistance. As in our study they also found a fall in $\mathrm{PaCO}_{2}$, apparently due to an increase in minute ventilation. Despite this, and in contrast to our study, $\mathrm{PaO}_{2}$ fell sharply and significantly; we agree with their conclusion that this was due to the more profound pulmonary vasodilatation they observed exacerbating ventilation-perfusion mismatching.

Several studies have shown that ANP levels are elevated in pulmonary hypertension, whether due to various lung diseases ${ }^{344142}$ or to cardiac failure..$^{43}$ In this study we have found evidence that the concentrations of ANP found in severe pulmonary hypertension may selectively reduce right ventricular afterload in patients with hypoxic COPD. Thus a negative feedback loop may exist in which ANP release is increased to ameliorate the harmful effects of pulmonary hypertension on the pulmonary vasculature and right heart. The beneficial acute effects of low dose ANP suggest that drugs which inhibit its metabolism may have therapeutic potential in COPD.

TKR was supported by a research fellowship from BristolMyers Squibb Pharmaceuticals Ltd. We are indebted to Mrs Margaret Ashley and Mrs Margaret Dugas for nursing help.

1 Matthay RA, Niederman MS, Wiedemann MD. Cardiovascular-pulmonary interaction in chronic obstructive pulmonary disease with special reference to the pathogenesis and management of cor pulmonale. Med Clin North Am 1990;74:571-618.

2 Anonymous. Pulmonary hypertension: new information from necropsy-based studies. Lancet 1988;i:1315-6.

3 Spiro SG, Hahn HL, Edwards RHT, Pride NB. An analysis of the physiological strain of submaximal exercise in patients with chronic obstructive pulmonary disease. Thorax 1975;30:415-25.

4 Ude AC, Howard P. Controlled oxygen therapy and pul-

monary heart failure. Thorax $1971 ; 26: 572-8$.
5 Howard $P$. Vasodilator drugs in chronic obstructive airways disease. Eur Respir 7 1989;7(Suppl):678s-81s.

6 Whyte KF, Flenley DC. Can pulmonary vasodilators im- 
prove survival in cor pulmonale due to hypoxic chronic bronchitis and emphysema? Thorax 1988;43:1-8.

7 Seibold H, Bunjes D, Schmidt A, Hombach V. Pathophysiological aspects of predominant preload lowering on pulmonary circulation, gas exchange, and the biventricular function in patients with chronic obstructive lung disease. Clin Cardiol 1988;11:630-8.

$8 \mathrm{MacNee}$ W, Wathen CG, Hannan WH, Flenley DC, Muir AL. Effects of pirbutertol and sodium nitroprusside on AL. Effects of pirbutertol and sodium nitroprusside on
pulmonary haemodynamics in hypoxic cor pulmonale. pulmonary haemodynamic

9 Agostoni P, Doria E, Galli C, Tamborini G, Guazzi MD. Nifedipine reduces pulmonary pressure and vascular tone during short- but not long-term treatment of pulmonary hypertension in patients with chronic obstructive pulmonary disease. Am Rev Respir Dis 1989;139:120-5.

10 Bratel T, Hedenstierna G, Nyquist $O$, Ripe $E$. The use of a vasodilator, felodipine, as an adjuvant to long-term oxygen treatment in COLD patients. Eur Respir f 1990;3:4654 .

11 Brent BN, Berger HJ, Matthay RA, Mahler D, Pytlik L, Zaret BL. Contrasting effects of vasodilators (nitroglycerin, nitroprusside, and hydralazine) on right ventricular cerin, nitroprusside, and hydralazine) on right ventricular performance in patients with chronic obstructive pulmonary disease and pulmonary hypertension: a combined radionuclide-hae

12 Neilly JB, Carter R, Tweddel A, Martin W, Hutton S, Banham SW, et al. Long term haemodynamic, pulmonary function and symptomatic effects of pirbuterol in COPD. Respir Med 1989;83:59-65.

13 Adnot S, Chabrier PE, Brun-Buisson C, Viossat I, Braquet $\mathrm{P}$. Atrial natriuretic factor attenuates the pulmonary pres-
sor response to hypoxia. $7 \mathrm{Appl}$ Physiol $1988 ; 65: 1975-83$.

14 Sakamoto M, Nakao K, Morii N, Sugawara A, Yamada T, Itoh $\mathrm{H}$, et al. The lung as a possible target organ for atrial natriuretic polypeptide secreted from the heart. Biochem natriuretic polypeptide secreted from the

15 Raffestin B, Levame M, Eddahibi S, Viossat I, Braquet P, Chabrier PE, et al. Pulmonary vasodilatory action of endogenous atrial natriuretic factor in rats with hypoxic pulmonary hypertension. Effects of monoclonal atrial natriuretic factor antibody. Circ Res 1992;70:184-92.

16 Stewart AG, Thompson JS, Rogers TK, Morice AH. Atrial natriuretic peptide-induced relaxation of preconstricted isolated rat perfused lungs: a comparison in control and hypoxia-adapted animals. Clin Sci 1991;81:201-8.

$17 \mathrm{Ou}$ LC, Sardella GL, Hill NS, Thron CD. Does atrial natriuretic factor protect against right ventricular overload? I. Haemodynamic study. $f$ Appl Physiol 1989;67:1606-11.

18 Jansen TL, Morice AH, Brown MJ. A comparison of the vasodilator responses to atrial peptides in the pulmonary and renal arteries of the pig in vitro. $\mathrm{Br} \mathcal{F}$ Pharmacol 1987;91:687-91.

19 Numan NA, Gillespie MN, Altiere RJ. Pulmonary vasorelaxant activity of atrial peptides. Pulmonol Pharmacol 1990;3:29-33.

20 Rogers TK, Stewart AG, Morice AH. Effect of chronic hypoxia on rat pulmonary resistance vessels: vasodilatation by atrial natriuretic peptide. Clin Sci 1992;83:7239.

21 Lindberg F, Andersson KE. Vasodilator responses to alpha-human-atrial natriuretic peptide in isolated omental and pulmonary arteries from rabbit and man. Acta tal and pulmonary arteries from
Physiol Scand 1988;134:391-7.

22 Labat C, Norel X, Benveniste J, Brink C. Vasorelaxant effects of atrial peptide II on isolated human pulmonary muscle preparations. Eur $\mathcal{F}$ Pharmacol 1988;150:397-400.

23 Abell TJ, Richards AM, Ikram H, Espiner EA, Yandle T. Atrial natriuretic factor inhibits proliferation of vascular smooth muscle cells stimulated by platelet-derived growth factor. Biochem Biophys Res Commun 1989;160:1392-6.

24 Jin H, Yang RH, Chen YF, Jackson RM, Oparil S. Atrial natriuretic peptide attenuates the development of pul- monary hypertension in rats adapted to chronic hypoxia. f Clin Invest 1990;85:115-20.

25 Stewart AG, Sheedy W, Thompson JS, Morice AH. Effects of SCH 34826, a neutral endopeptidase inhibitor, on hypoxic pulmonary vascular remodelling. Pulmonol Pharmacol 1992;5:111-4.

26 Winter RJ, Zhao L, Krausz T, Hughes JM. Neutral endopeptidase 24.11 inhibition reduces pulmonary vascular
remodeling in rats exposed to chronic hypoxia. Am Rev remodeling in rats exposed

27 Adams SP. Structure and biologic properties of the atrial natriuretic peptides. Endocrinol Metab Clin North $\mathrm{Am}$ 1987;16:1-17

28 Richards AM, Wittert G, Espiner EA, Yandle TG, Frampton C, Ikram H. EC 24.11 inhibition in man alters clearance of atrial natriuretic peptide. $\mathcal{F}$ Clin Endocrinol Metab 1991;72:1317-22.

29 Adnot S, Andrivet P, Chabrier PE, Piquet J, Plas P, Braquet $\mathrm{P}$, et al. Atrial natriuretic factor in chronic obstructive lung disease with pulmonary hypertension. Physiological correlates and response to peptide infusion. 7 Clin Invest 1989;83:986-93.

30 Morice A, Pepke-Zaba J, Loysen E, Lapworth R, Ashby M, Higenbottam $T$, et al. Low dose infusion of atrial natriuretic peptide causes salt and water excretion in normal man. Clin Sci 1988;74:359-63.

31 West JB. Pulmonary pathophysiology. Baltimore, London: Williams and Wilkins, 1987

32 Armitage P, Berry G. 9.4 Regression in groups. In: Statistical methods in medical research. Oxford: Blackwell, 1987:273-82.

33 Stewart AG, Bardsley PA, Baudouin SV, Waterhouse JC, Thompson JS, Morice $\mathrm{AH}$, et al. Changes in atrial natriuretic peptide concentrations during intravenous saline infusion in hypoxic cor pulmonale. Thorax saline infusion

34 Morice AH, Pepke-Zaba J, Brown MJ, Thomas PS, Higenbottam TW. Atrial natriuretic peptide in primary pulmonary hypertension. Eur Respir f 1990;3:910-3.

35 Cody RJ, Atlas SA, Laragh JH, Kubo SH, Covit AB, Ryman KS, et al. Atrial natriuretic factor in normal subjects and heart failure patients: plasma levels and renal, hormonal and hemodynamic responses to peptide infusion. $\mathcal{F}$ Clin Invest 1986;78:1362-72.

36 Herrmann HC, Rosenthal AD, Davis CA. Cardiovascular effects of intracoronary atrial natriuretic peptide administration in man. Am Heart $\mathcal{f} 1990 ; 120: 308-15$

37 Münzel T, Drexler H, Holtz J, Kurtz S, Just H. Mechanisms involved in the response to prolonged infusion of atrial natriuretic factor in patients with chronic heart atrial natriuretic factor in patients
failure. Circulation 1991;83:191-201.

38 Goy JJ, Waeber B, Nussberger J, Bidiville J, Biollaz J, Nicod $\mathrm{P}$, et al. Infusion of atrial natriuretic peptide to patients with congestive heart failure. $\mathcal{f}$ Cardiovasc Pharmacol 1988;12:562-70.

39 Groban L, Ebert TJ, Kreis DU, Skelton MM, van Wynserghe DM, Cowley AW. Haemodynamic, renal and hormonal responses to incremental ANF infusions in humans. Am F Physiol 1989;256:F780-6.

40 Westendorp RGJ, Roos AN, vd Hoeven HG, Tjiong MY, Simons $\mathrm{R}$, Frolich $M$, et al. Atrial natriuretic peptide improves pulmonary gas exchange in subjects exposed to hypoxia. Am Rev Respir Dis 1993;148:304-9.

41 Adnot S, Chabrier PE, Andrivet P, Viossat I, Piquet J, Brun-Buisson C, et al. Atrial natriuretic peptide concenBrutions and pulmonary hemodynamics in patients with trations and pulmonary hemodynamics in patients with pulmonary artery hyperten
Respir Dis 1987;136:951-6.

42 Mitaka C, Hirata Y, Nagura T, Sakanishi N, Tsunoda Y, Amaha K. Plasma alpha-human atrial natriuretic peptide concentration in patients with acute lung injury. $A m$ Rev Respir Dis 1992;146:43-6.

43 Kokubu T, Nagae A, Hiwada K, Kazatani Y, Joh T, Matsuo H. Pulmonary arterial pressure and plasma concentration of atrial natriuretic factor (ANF) in patients with heart disease. Fap Heart $f$ 1986;27:791-6. 